$1-1-1957$

\title{
Competition and apple prices : with emphasis on processors in the Appalachian area
}

Homer C. Evans

Follow this and additional works at: https://researchrepository.wvu.edu/ wv_agricultural_and_forestry_experiment_station_bulletins

\section{Digital Commons Citation}

Evans, Homer C., "Competition and apple prices : with emphasis on processors in the Appalachian area" (1957). West Virginia Agricultural and Forestry Experiment Station Bulletins. 406.

https://researchrepository.wvu.edu/wv_agricultural_and_forestry_experiment_station_bulletins/391 @ WVU. It has been accepted for inclusion in West Virginia Agricultural and Forestry Experiment Station Bulletins by an authorized administrator of The Research Repository @ WVU. For more information, please contact ian.harmon@mail.wvu.edu. 


$$
7
$$

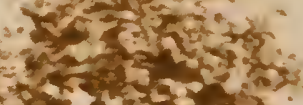

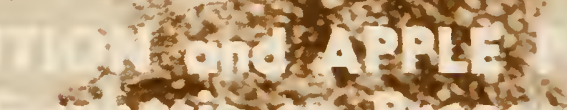

$+5$

\% 0.54

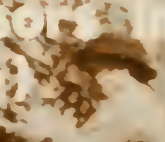

W. W n H. H. H.

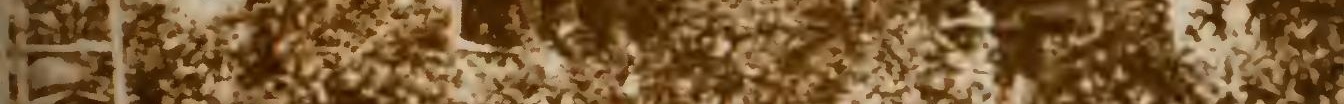

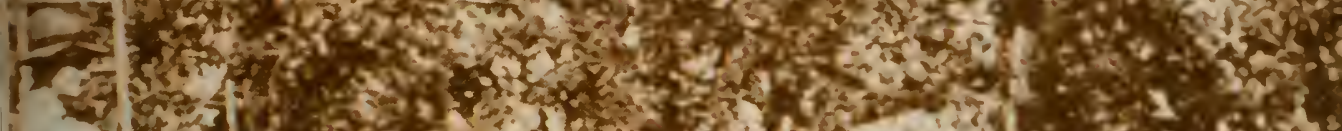
Ha

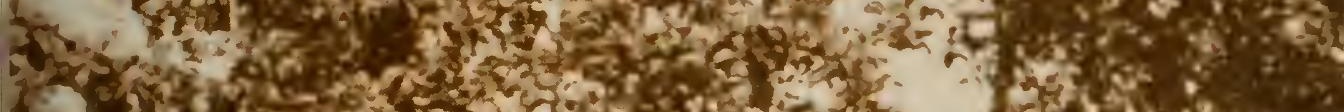
$5012, x^{2}, 5$

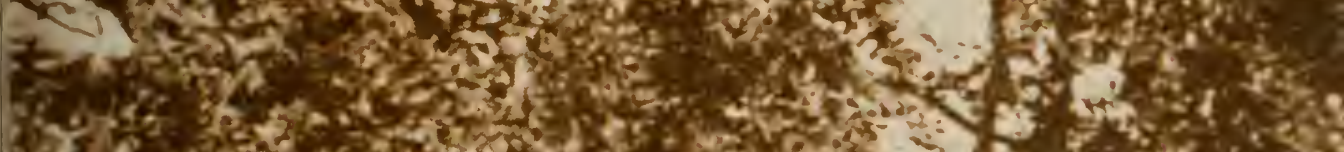

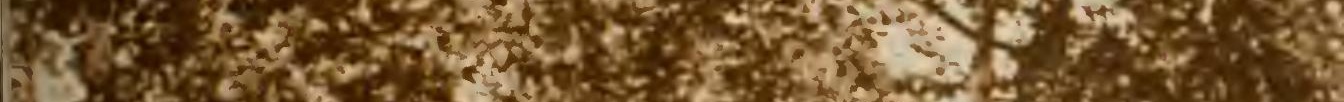

(1)

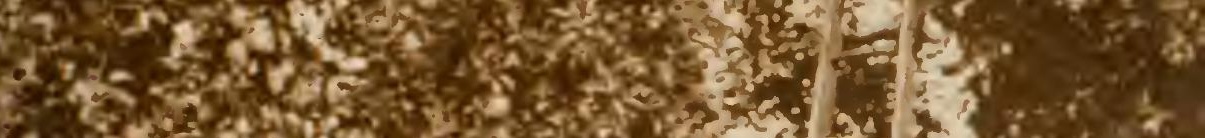

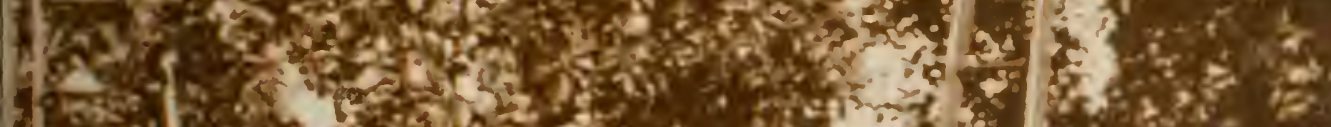

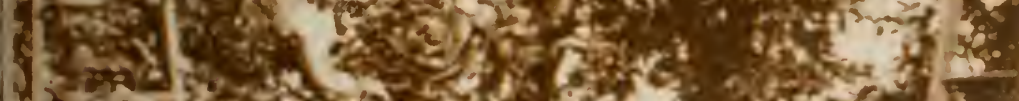

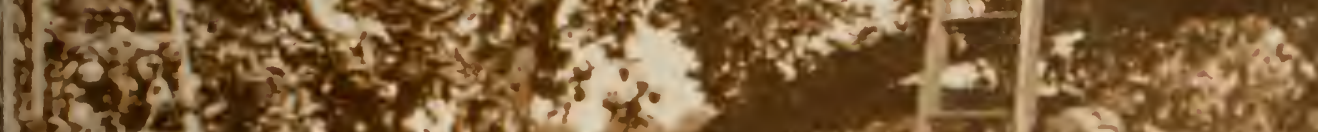

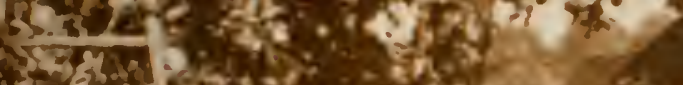

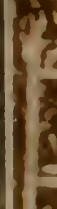

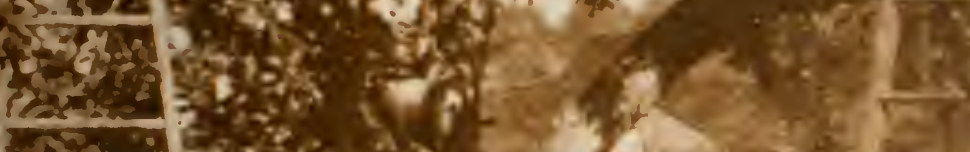




\section{Summary}

The Appalachian Area produces about one-fifth of the national com mercial apple crop. Production has been declining both in the United States and in the Appalachian Area. Nevertheless, sales to processors have increased during the last 20 years. The production of sance and slices has expanded, especially the production of sance. In the Ap. palachian Area approximately one-half of the crop has been sold in recent years to processor outlets. About one-half of the national produc tion of sance and slices is produced here.

Six processors do most of the apple processing in the area. One firn generally announces an opening price for apples, and all other firms follow with similar if not identical prices. These conditions, taken alone suggest the possibility of more profits and less output than would be the case under perfect competition.

Indications are that the supply of apples available to processors ir the Appalachian Area is clastic and dependent upon processor price relative to price paid lor fresh apples. Also, data indicate that process ing costs per unit do not vary within the present range of processo: capacities.

An effective cooperative firm is present in the Appalachian Area which returns to its patrons all receipts over costs of operation. Othes firms meet this competition by paying bonuses to their suppliers. Im plicit price deals are widely used. These actled returns encourage apple growers to sell more apples to the processors.

The entry of new firms into the processor sub-group is relativel: easy. Three firms have entered since 1939 , and in recent years they have been doing between one-fourth and one-third of the total processing is the area.

From this analysis of the situation, it appears that competition among processors is strong and there is little opportunity for exces profits over a period of time. This means that the processor price $i$ efficient in the allocation of apples between fresh and processor outlets

WEST VIRGINIA UNIVERSITY

Agricultural Experiment Station

Collfge of Agriculture, forestry, and Home Economics

H. R. VARney, Director

MORGANTOWN 


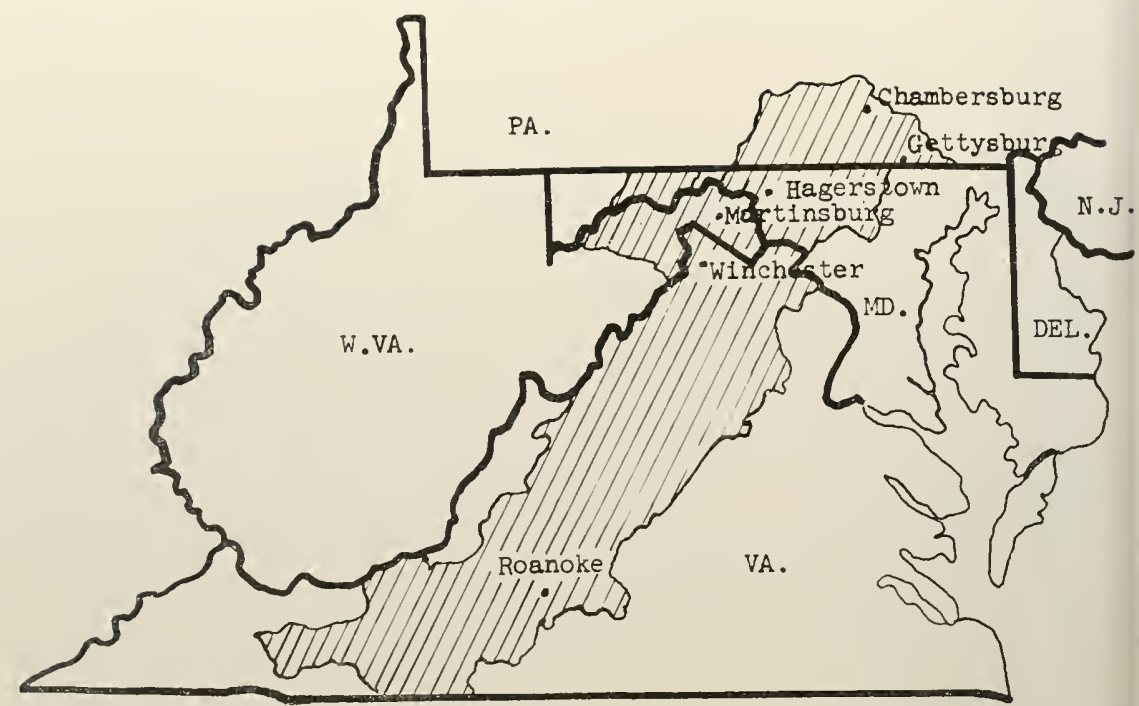

FIGURE 1. Appalachian Area (outline of commercial apple producing sections of Pennsylvania, Maryland, West Virginia, and Virginia).

For two firms to be in the same market they must meet two requirements: they must sell (or buy) substitute products, and they must be confronted with similar technological, market, and organization problems; that is, they must belong to the same industry. Therefore, the firms in a market are relatively homogeneous, are confronted by similar problems, and are in relatively close competitive relationship. Perhaps market sub-group would be a better term than market to describe such a group of buyers or sellers. It is within a market sub-group that sellers compete actively with one another, buyers and sellers bargain actively with one another, and price is established.

Each market sub-group is composed of a group of buyers and a greup of sellers. Therefore, any apple processor, in addition to other buyers, also is confronted with apple sellers.

Before attempting to outline the market sub-group which includes apple processors, a brief historical account of the production and utiliration of apples is presented, with particular emphasis on the Appalachian Area. This account will give some idea of the environment in which apple sellers and buyers operate.

\section{Apple Production}

Production of apples has been reperted in every state in the union, but commercial production is limited to 35 states. Figure 2 gives the distribution of apple trees in the United States. The bulk of the 


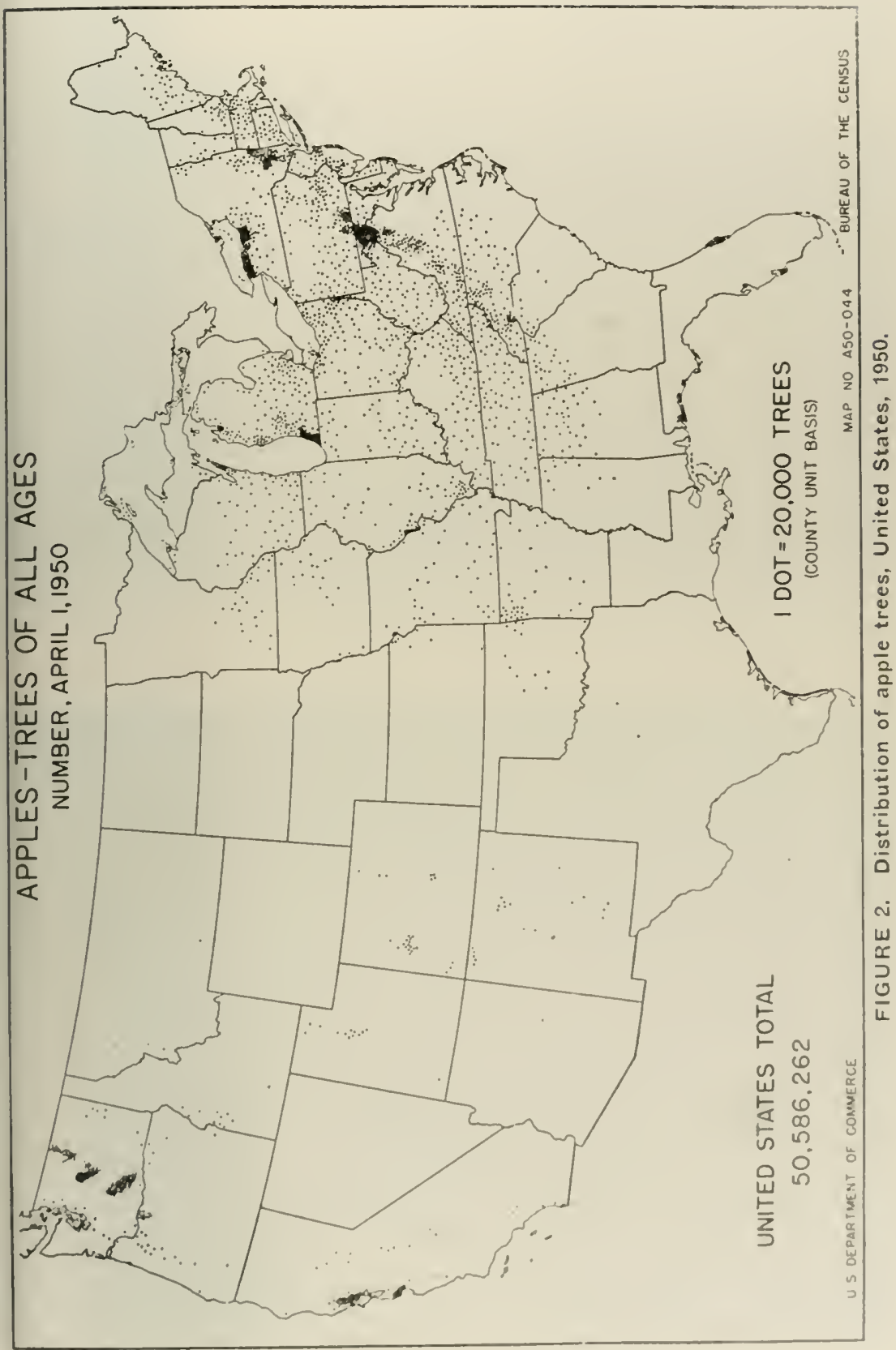




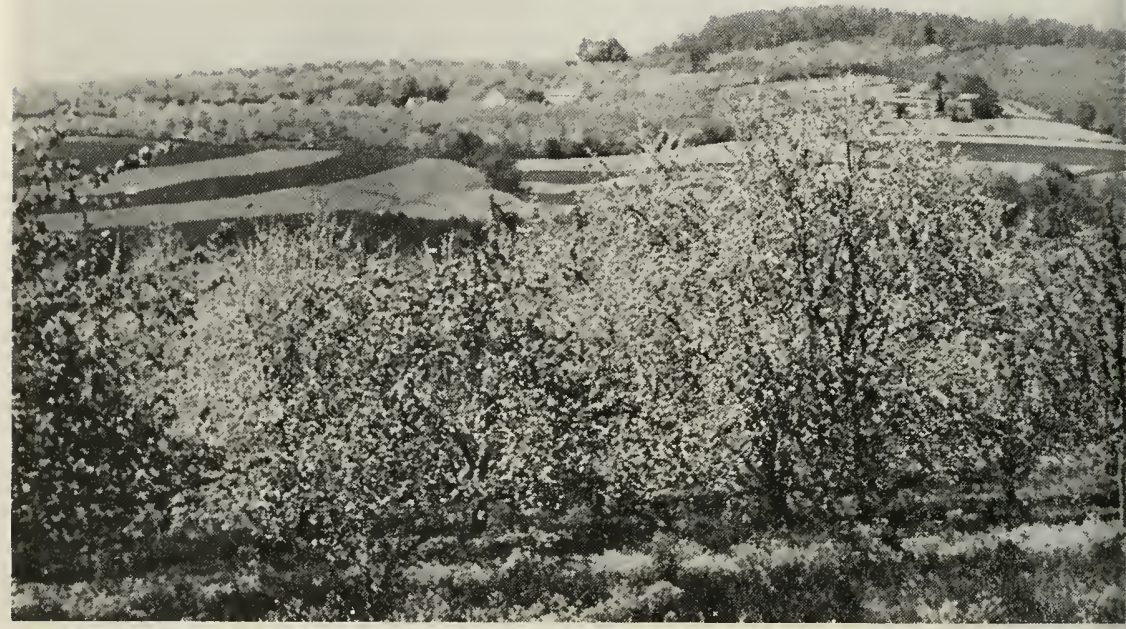

THE APPALACHIAN AREA produces approximately one-fifth of the national apple crop.

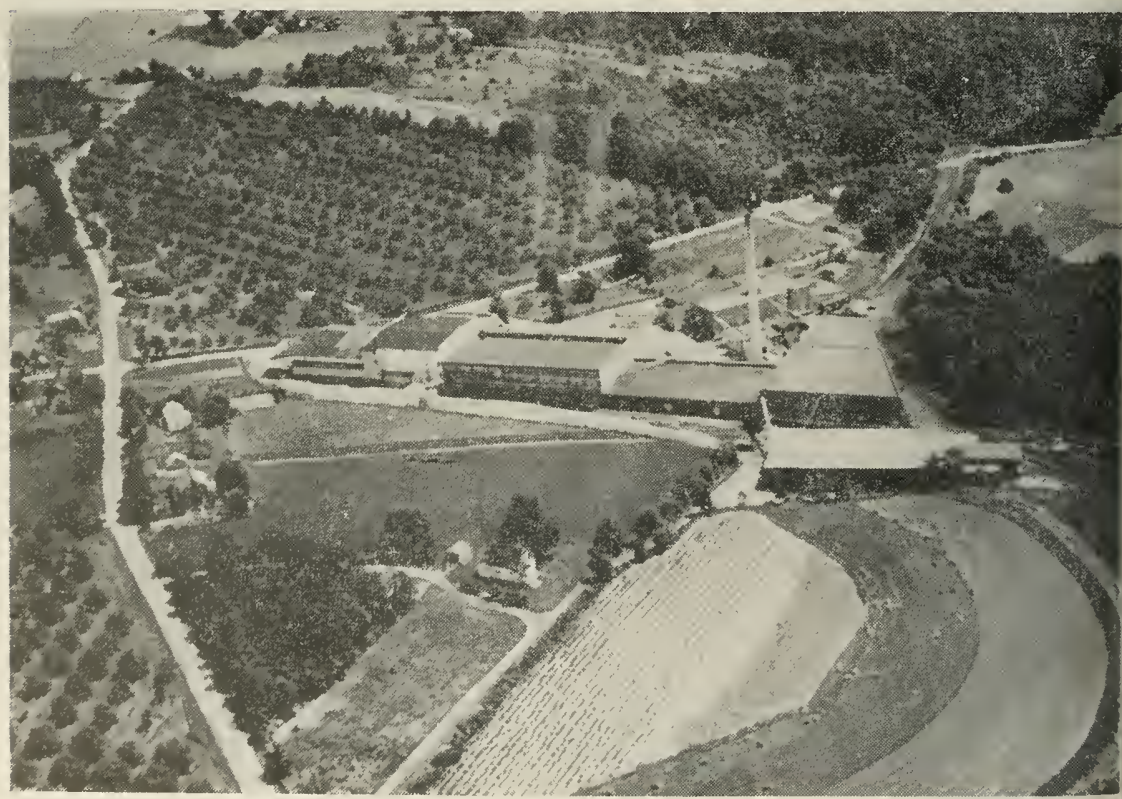

MODERN processing plant surrounded by orchards. 
commercial production is concentrated in a few areas. Washington State has been the most important area in recent years, accounting for about one-fourth of the commercial crop. The Appalachian . Irea i, second, producing approximately one-fifth of the total crop. Now York state is third, accomuting for slightly less than the Appalachian Area. Michigan and Califomia produce maller, but important, quantitics. Production of the remaining one-fourth of the crop is scattered over sevcral states, chiefly those east of the Mississippi River. Nbout two-thirds of the national crop comes from an area extending about 500 miles, mostly to the north and west from the Appalachian Area, Figure 2.

Average annual commercial production in the ('nited States from 1934 to 1954 was $112,560,000$ bushels, Figure 3 . During the same period there was an average annual decrease of $1,126,000$ bushels.

Production in the Appalachian Area has followed a trend similat to that for the United States and has tended to decline over the period 1934-195. with an average annual decrease of 511,000 bushels, Figure 1.

\section{Utilization}

While total national production has been declining, sales to processors have been increasing. From 1934 to 1954 annual sales to processors averaged 28,760,000 bushels, or about 25 per cont of the crop.

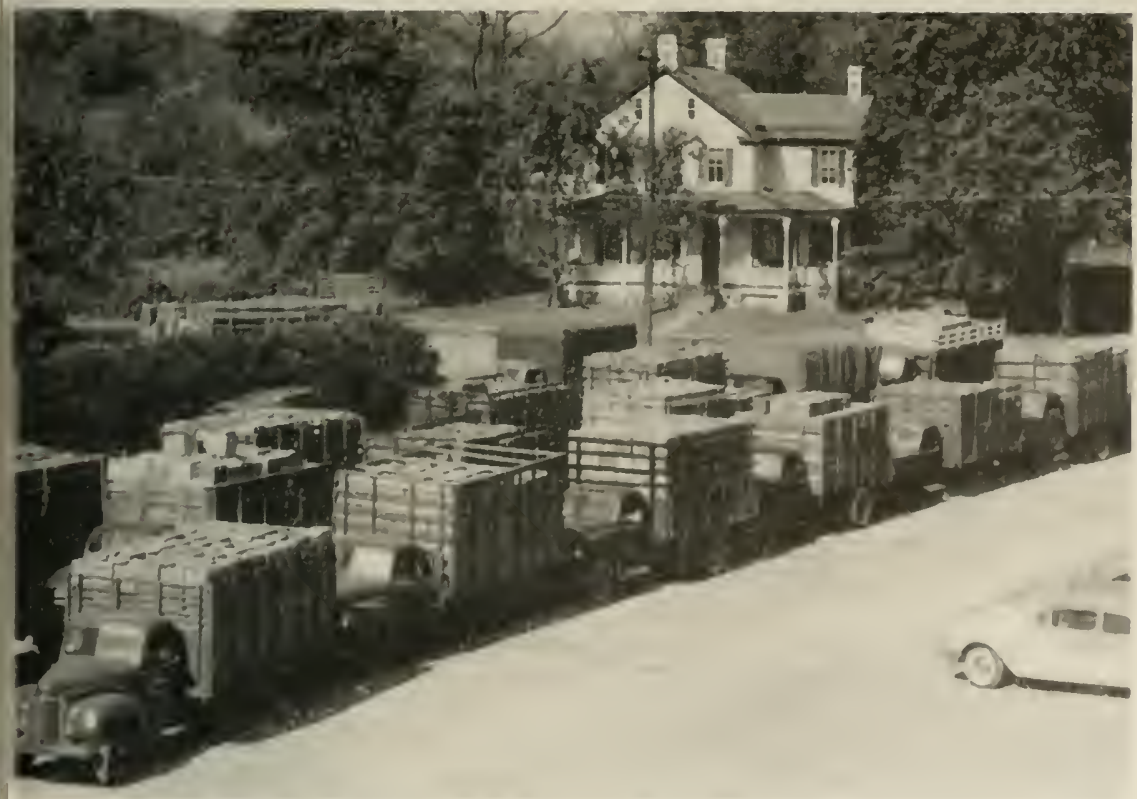

APPLES being delivered to processors. 


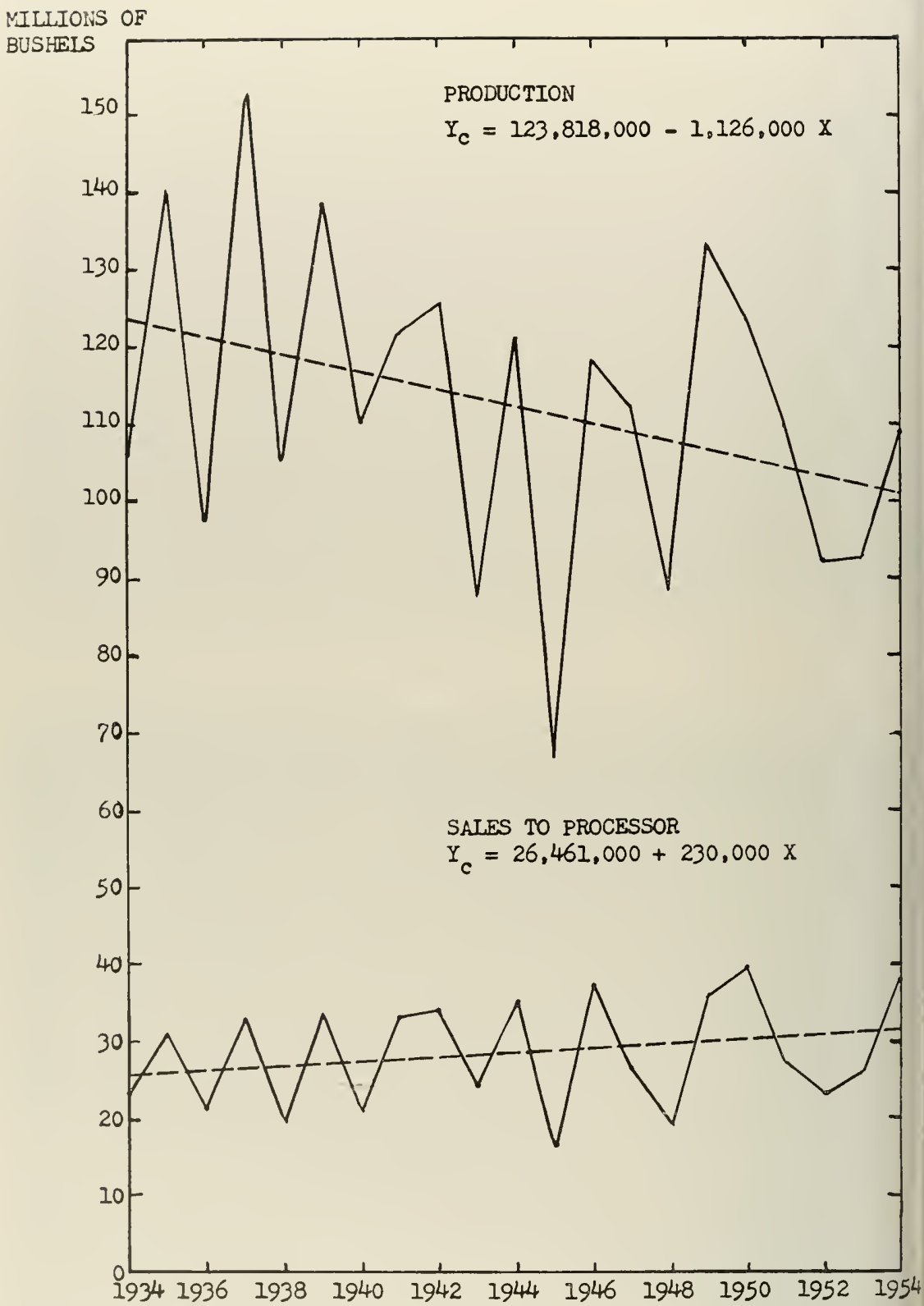

FIGURE 3. Apples-Production and trend in production of commercial crop; sales to the processor and trend in sales, United States, 1934-54. (Source: United States Department of Agriculture, Crop Reporting Board.) 


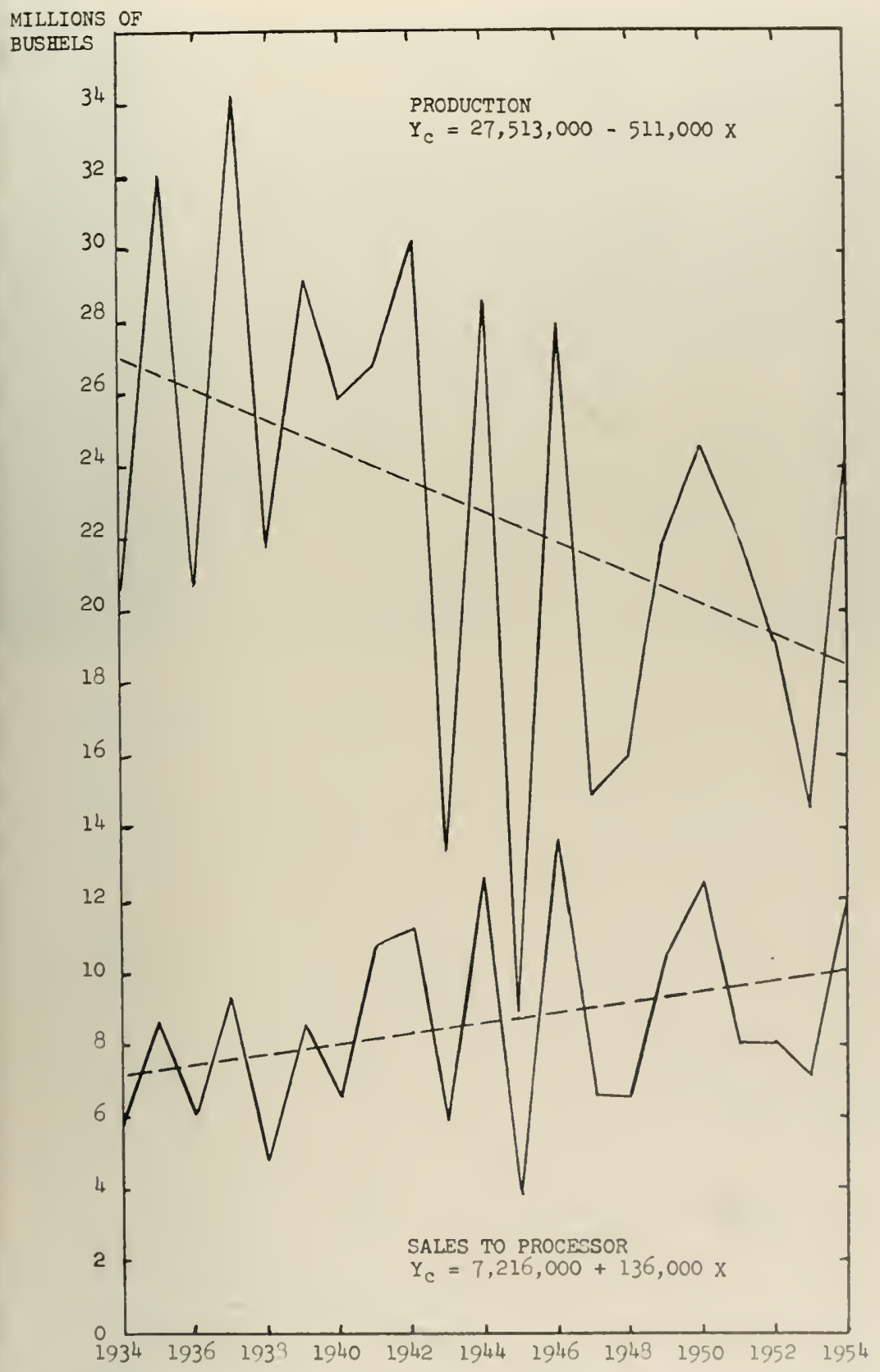

FIGURE 4. Apples-Production and trend in production of commercial crop: sales to the processor and trend in sales, Appalachian Area, 193454. (Source: United States Department of Agriculture, Crop Reporting Board.) 


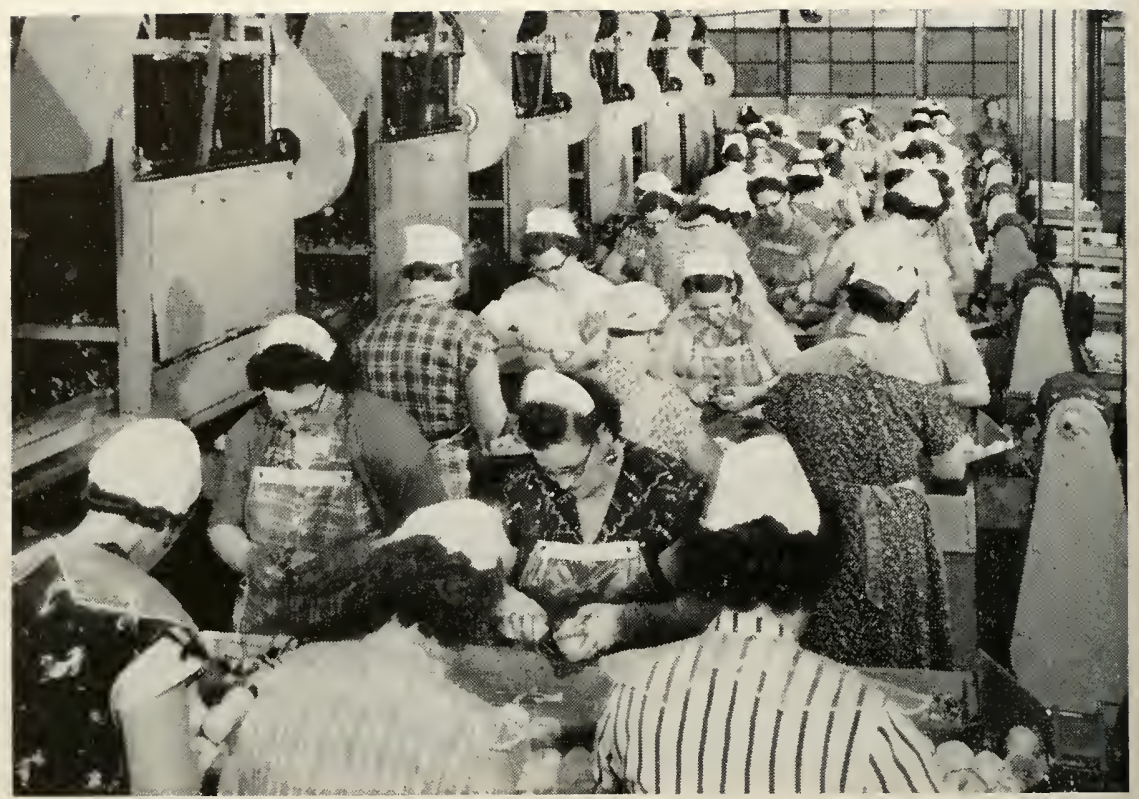

TRIMMING apples.

Figure 3. During the same period an annual average increase of 230,000 bushels was going to processors.

In the Appalachian Area, sales to processors have increased. During the period 1934-54 there was an average annual increase of 136,000 bushels, Figure 4. In recent years approximately one-half of the crop in the Appalachian Area has been sold to processors.

Although there appears to be a rather high degree of substitution among varieties of apples, some rarieties are better suited for some uses than others. Red Delicious, MrIntosh, and Winesap are preferred for Iresh use, whereas Gravenstein, Greening, York, and Baldwin are prelerred for processing. Stayman, Rome Beauty, Golden Delicious, and Crimes Golden are considered desirable by either the fresh or processing outlets. Nithough there is a rather wide distribution of each variety, the Appalachian Area and New-rork state produce a large proportion of processing and dual purpose varieties.

Applesauce and slices are the principal apple products produced both in the United States and in the Appalachian Area. Table 1 gives the total pack of sauce in the United States and the percentage of sance packed in the various areas. The Appalachian Area supplies approximately onc-half of the total pack, followed by New York and California, Table 2 gives the total pack of sliced apples in the United States and the percentage packed in the various areas and states. Again the Ap- 
Table 2. Sliced Apples-Total Pack United States and Percentage Distribution by States or Groups of States, I934-1954

\begin{tabular}{|c|c|c|c|c|c|}
\hline \multirow[b]{2}{*}{ YEAR } & \multirow{2}{*}{$\begin{array}{c}\text { U.S. } \\
\text { (Thousand } \\
\text { CASES) }\end{array}$} & \multicolumn{4}{|c|}{ PER CENT OF U. S. PACK } \\
\hline & & $\begin{array}{l}11_{D}, P_{A .,} \\
\text { VA., W. } \\
\end{array}$ & N. Y. & $\begin{array}{c}\text { WASH., } \\
\text { ORE. }\end{array}$ & Others \\
\hline 1934 & 2,584 & - & - & 一 & 一 \\
\hline 1935 & 2,331 & - & - & - & - \\
\hline 1936 & 2,620 & 34.2 & 4.1 & 59.1 & 2.6 \\
\hline 1937 & 2,672 & 53.5 & 9.7 & 35.1 & 1.7 \\
\hline 1938 & 1,750 & 49.7 & 11.6 & 37.1 & 1.6 \\
\hline 1939 & 2,840 & 48.9 & 14.2 & 36.2 & 0.7 \\
\hline 1940 & 2,249 & 52.8 & 13.7 & 32.5 & 1.0 \\
\hline 1941 & 4,348 & 51.4 & 13.0 & 31.0 & 4.6 \\
\hline 1942 & $4,16 t$ & 61.4 & 15.6 & 21.6 & 1.4 \\
\hline 1943 & 1,878 & 51.3 & 23.1 & 24.8 & 0.8 \\
\hline 1944 & 3,355 & 60.8 & 18.7 & 19.0 & 1.5 \\
\hline 1945 & 1,191 & 73.8 & a & 25.7 & 0.5 \\
\hline 1946 & 3,266 & 58.6 & 22.7 & 14.1 & 4.6 \\
\hline 1947 & 2,241 & 54.2 & 33.2 & 11.0 & 1.6 \\
\hline 1948 & 1,687 & 58.5 & 28.5 & 11.9 & 1.1 \\
\hline 1949 & 4,213 & 56.6 & 27.6 & 8.8 & 7.0 \\
\hline 1950 & 5,264 & 59.5 & 21.9 & 14.7 & 3.9 \\
\hline 1951 & 3,388 & 60.1 & 29.4 & 7.4 & 3.1 \\
\hline 1952 & 2,560 & 60.8 & 27.5 & 8.6 & 3.1 \\
\hline 1953 & 2,941 & 47.2 & 34.7 & 12.8 & 5.3 \\
\hline 1954 & 4,709 & 56.0 & 27.9 & 9.7 & 6.4 \\
\hline
\end{tabular}

$\mathrm{a}=$ Included in other states.

Source: National Canners Association, Washington, D.C.

The prices of all grades, varieties, and sizes of apples are closely related and tend to move together due to their high degree of substitu tion. Also, all market places are tied together because apple seller: substitute one market place for another. For example, if farmer A car realize a higher f.o.b. orchard price for his apples by selling in Chicagc than by selling in Atlanta, he will tend to substitute Chicago for Atlant: until returns are the same. In the same way he determines whether to sell to the fresh or processor outlets. Therefore, all apple growers ar selling substitute products.

Technological, marketing, and organizational problems which con front farmer $\mathrm{A}$ in the production of apples are simliar to those confront ing all other apple growers. Although apples are produced over a larg part of the United States, the bulk of the commercial crop is producec in four areas, Figure 2. The time necessary to establish a producing orchard is about the same in each area. In the various areas the lengtl of growing season and production costs present similar problems. Cost are somewhat higher in some areas than in others, but in general, yield in these areas also will be higher. 


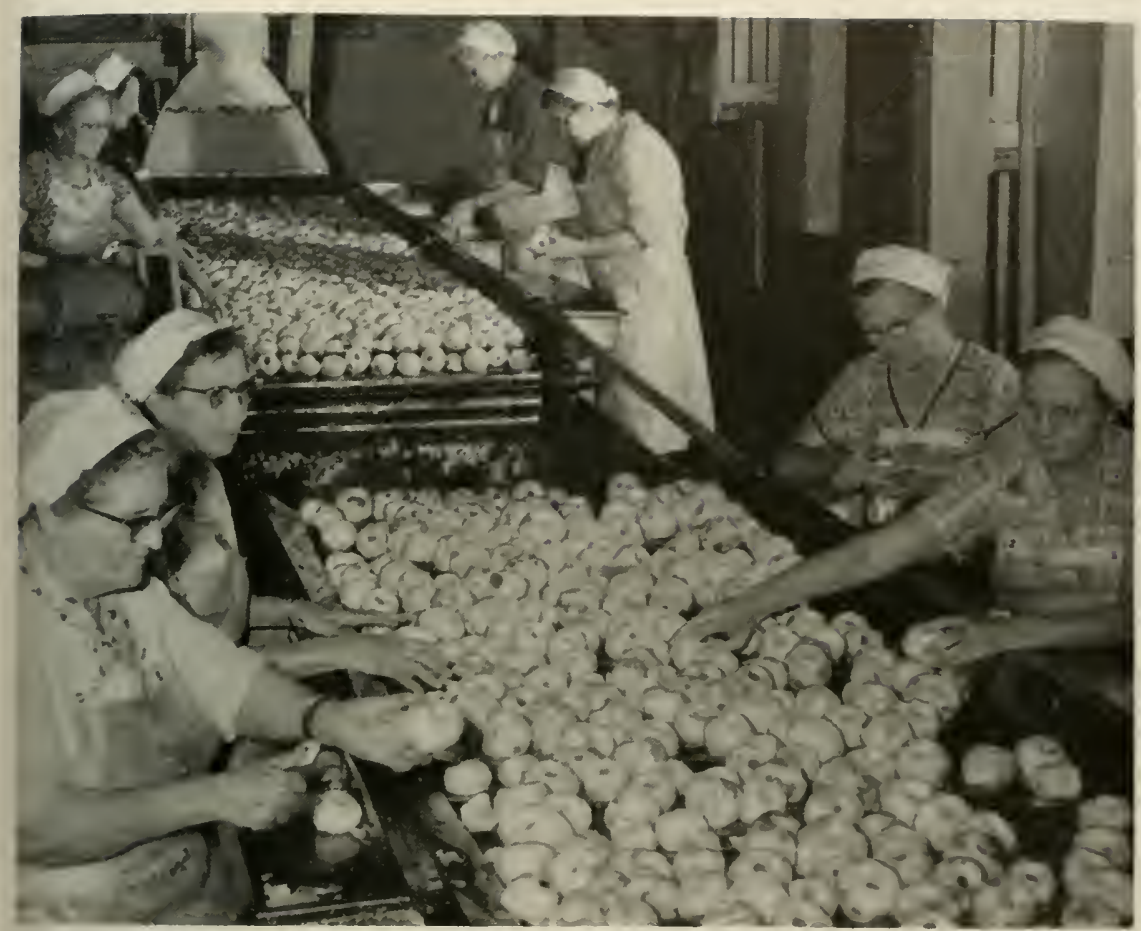

INSPECTING peeled apples.

The reather presents many problems for apple growers. Frost, winter freez, drought, and hail are some of the major problems. Certainly, the probability of any one of these occmring varic's among ancas. However, there maty be certain oflsetting eflects. For example, winter freese seems to be an important havard in the Pacific Northwest, whereas pring frosts are important in the East. The temperature and amount of smoshine aflect the finish of the fruit, and some arean are partirulaty favored in this respect. This toncls to diflerentiate the fruit of these areas from the fruit of others.

All prolucing ancas sell through the same matket places. Some areas depend more on processor omtets than do others. Hewerer. for ally grower there appears to be a mumber of altermative manket plares. The maketing problems confmoting all apple producers ate yuite similar.

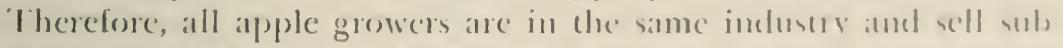
stitute products. This qualifes all such growers for the s.tme monher sul)-gromp, as defincel in this study.

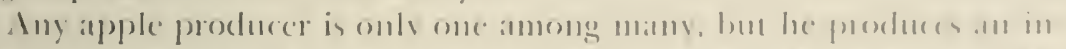

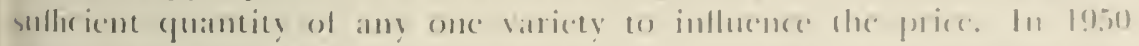

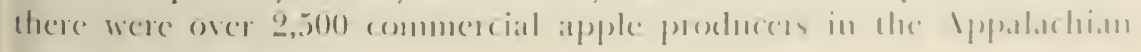




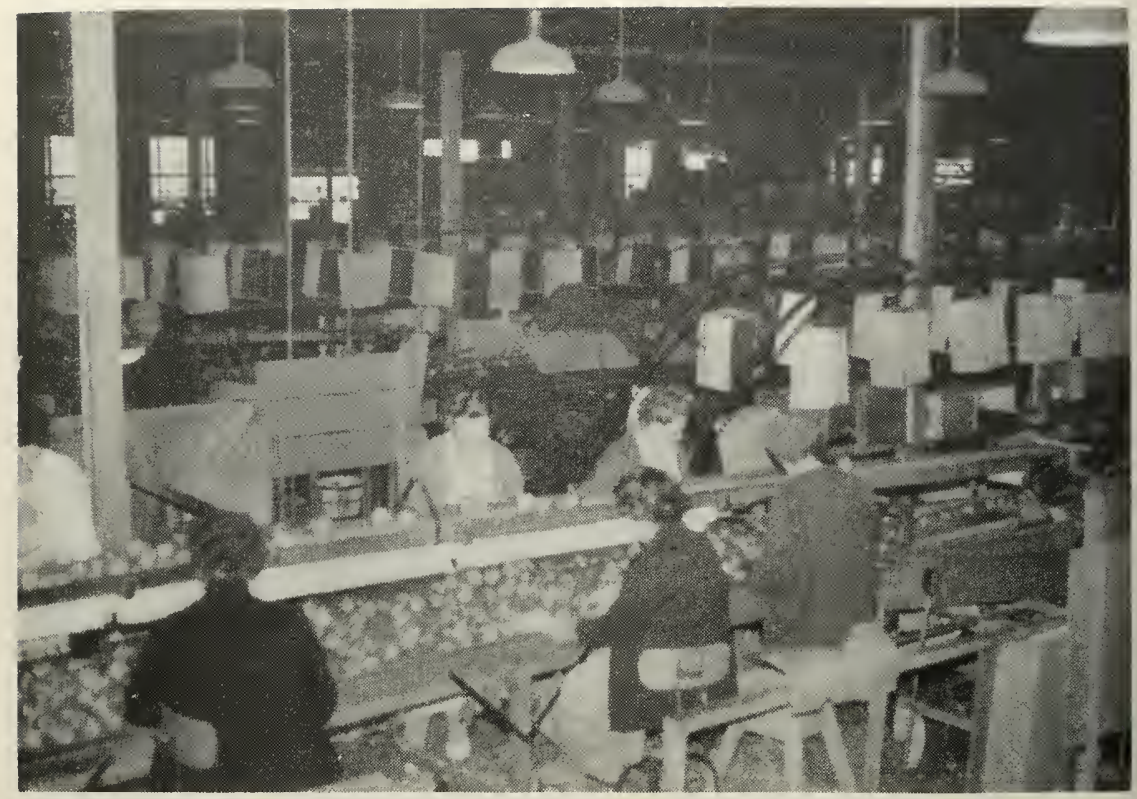

MODERN fresh packing plant-about one-half of the crop in the Appalachian Area goes to the fresh market.

Area. The 1950 Census of Agriculture reported over 1.5 million farms producing apples.

Each grower is a price taker. He may decide how much to produce and sell, but he must take price as given. Even though these are factors which deviate from the purely competitive situation, apple growers in the marketing of their apples act basically as though they were selling under conditions of pure competition. Each seller has such a small volume relative to the market sub-group that he exerts no perceptible inlluence on the price of apples; new growers may freely enter apple production and their decision to do so is of no concern to those already producing and selling apples; and knowledge of alternatives is rather complete.

\section{Competition Among Apple Buyers}

In the Appalachian Area apple sales are divided almost equally between fresh and processor outlets. Competition among buyers of fresh apples is similar to competition among apple sellers. Growers freely substitute one buyer of fresh apples for another. Buyers of fresh apples have similar problems in that they handle the same product (apples) and perform the same function. Due to the large number of buyers, each 
1. Fresh price appears to be established on a national basis under conditions approaching those of pure competition. The quantity of apples received by processors in the Appalachian Area is determined largely by the price of apples for processing relative to fresh apple prices. This is outside the control of processors. A rough approximation of this relationship is presented in Figure 5 . The solid line represents an index of the ratio of processor prices to fresh prices in the Ap palachian Area, and the broken line represents an index of processon purchases to fresh purchases. The two generally move together with sales tending to fluctuate more than price. This indicates that the sup ply confronting processors in the Appalachian Area is elastic. ${ }^{3}$ The more elastic the supply curve the less the opportunity for excess profits Therefore, the nature of the supply of apples available to processor: rather restricts the opportunity for excess profits.

Also, processors buy on the basis of United States Grades and Stan dards. This facilitates the comparisons of offers by the different process ors. In most cases each grower sells to more than one processor. Con sequently, the supply available to any particular processor is dependen upon its price relative to other processors. Therefore, the supply avail able to any one processor is even more elastic than that for all processor in the area.

2. The cooperative processor returns all receipts over costs of oper ation to patrons on a patronage basis. A five cents per cwt. differenc in price is enough to cause growers to switch sales from one processor $t_{1}$ another. Under conditions such as these the non-cooperative processo cannot afford to ignore patronage refunds on the part of a cooperative even though such refunds are made after the crop has been marketec Processors are concerned with their apple supplies and with the relativ future growth of other processors. Consequently, other processors mec the competition of the cooperative's patronage refund by paying bonuse: These patronage refunds and bonuses increase the returns to appl growers.

Although the patronige refunds and bonuses are made after th growers have decided how to market their crops, they tend to becom factors which are considered by growers in making marketing decisior because such payments have been made in the past and are expecte to be made in the future. Thus, alter patronage refunds and bonuse have become general practice, growers, when making marketing dec sions, not only consider the announced price but also assume that som thing more will be paid. This consideration may explain partially wh processors were deluged with apples in some recent years.

${ }^{3}$ The elasticity of demand or supply of a product is the: relative change in quanti - corresponding relative change in price. For example, if a 1 per cent increase in pri bring forth more than a 1 per cent increase in supply, the supply is elastic. 
at the price offered. Often they start as "secret deals" between individual growers and processors, but they fail to remain secret and soon become the general practice of all processors. These implicit price devices are employed for minor price adjustments in an effort by individual processors to attract apples from other processors. Such practices increase the growers' net returns and their sales to processors.

4. The ease of entry of new processing firms in a market sub-group influences the competitive behavior of the firms concerned. Both actual entry and potential entry appear to have moderating effects on the decisions of frrms to maximize short-rum profits. Existing processors tend to pay relatively higher apple prices in an attempt to combat the entry of new firms and to prevent their expansion after new firms have entered. Since 1939, three firms have entered successfully the sub-group of apple processors in the Appalachian Area.

5 . Indications are that size of processing firms has little effect on the relative cost of processing apples. Also, costs for individual firms appear to be constant over their nomal range of outputs. This indicates that one processor is about as efficient as any other processor. Such a situation maximizes the effectiveness of a cooperative and makes the entry of new firms relatively easy.

\section{Conclusion}

Competition among processors is strong and the price which they pay tends towards the purely competitive price. This means that processor price and output are efficient in the allocation of apples between the the fresh and processor outlets. It also indicates that in recent years the opportunity for excess profits among apple processors in the Appalachian Area has been reduced greatly if not eliminated.

Apple growers may help maintain this competitive market by: (1) being in a position to sell their apples through either the fresh or processor outlets and being on the alcrt to switch supplies to the outlet giving the highest net return; (2) keeping informed about the relative net returns from each processing furm and always being alert to switch supplies to the processor paying the highest net; and (3) supporting anc maintaining a strong cooperative processor.

Editor's Note: All photographs courtesy of Appalachian Apple Serv ice, Inc., and Area processors. 